\title{
Writing Baba Yaga into the Tasmanian Bush
}

Works of fiction come into being through mysterious routes of knowing. It's not at all unusual to hear a writer report that a story "came to them," as if stories were not things invented by writers, but preexisting entities floating in the ether. Elizabeth Gilbert is far from alone in her insistence that "ideas are a disembodied, energetic life form," and that they "spend eternity swirling around us, searching for available and willing human partners" (35).

A few years ago, I was visited in this mysterious way by the idea that I should write about a woman who lived in the Tasmanian bush in a small, timber hut, high on a hillside. It seemed that instantly I knew the following things: the woman rescued and nurtured marsupial creatures that were orphaned when their mothers were killed on the roads; there lived beneath the floorboards of her home a Tasmanian devil; the woman was ageing, or perhaps ageless; and she was a literary relative to Baba Yaga, the Slavic witch-crone of European fairy-tale tradition. This last piece of knowledge might have meant that I was being invited to perform a fairy-tale retelling, but because Baba Yaga (unlike most other fairy-tale characters) appears in a number of different tales, it was perhaps less of an invitation to retell a tale than to relocate a character and see what she would do in new surroundings.

Writers can say yes or no to the ideas that visit them. I said yes, and, because I am a writer with one foot in academia, I embarked on the quest to capture my Baba Yaga armed with the twin butterfly nets of creative practice and critical discourse. That is, I not only began the work of bringing my Baba Yaga into life on the page by imagining her world, exploring the narrative marvelstales.33.1.0157 Copyright @ 2019 by Wayne State University Press, Detroit, MI 48201. 
problem that I would present to her, finding a voice for her, and experimenting with point of view, I also began to read about Baba Yaga-in traditional tales, retellings, and works of criticism. As scholars in the field of fairy-tale studies already know, "retellings and criticism participate in a continuous and dynamic dialogue" (Joosen 3), and each has the ability to influence the other. The key questions that concerned me as I wrote and read were these: What has Baba Yaga stood for in the past, and what is she uniquely positioned to say right now? What has Baba Yaga already done, and what does she want to do next? And, what happens when you try to write a Slavic witch into the Tasmanian bush?

In a survey of over four hundred texts in which Baba Yaga appears, Andreas Johns found her most consistent attribute to be her "striking ambiguity" (30). In some tales, she is a helpful wise woman, in others a terrifying villain. In Proppian terms, she might occupy the role of villain or donor, but, even when she is the latter, she is frequently monstrous and threatening. Johns tentatively proposes that Baba Yaga's radical ambiguity was the result of a historical shift away from matriarchy: that her characterization as pagan wise woman was overlaid with more hideous attributes during a time of patriarchal reinvention (257). Indeed, in contemporary times, Baba Yaga has had things to say about gender. The ambiguities of power/powerlessness, as experienced by ageing women, is at the center of the book, which might be seen as the international exemplar of contemporary Baba Yaga retelling: Baba Yaga Laid an Egg (2010), by Dubravka Ugrešić.

On the rare occasions when Baba Yaga has been reinvented here in Australia, she has not been especially ambiguous. In the long story "By Bone-Light" (2014), written by the fairy-tale reinventionist Juliet Marillier and included in her collection Prickle Moon, Baba Yaga becomes Barbara Jaeger, an older woman who lives in the basement of an apartment block, and who is briefly ominous before becoming a source of maternal comfort to an orphaned young woman who lives upstairs. Meanwhile, within the fantastical multiculturalism of the Tashi series of children's books by mother-daughter team Barbara and Anna Fienberg, Baba Yaga is a classic cannibalistic monster outsmarted by a trickster hero.

While Baba Yaga has not yet had a strong presence in Australian creative works, she is clearly on people's minds. Even as an idea about Baba Yaga was visiting me, her legacy was touching the consciousness of Australian art photographer Lorena Carrington, whose image of Baba Yaga's house on legs has become a touchstone for my story. Says Carrington,

My illustration shows two children approaching the Baba Yaga's house. The trees loom black and the house creaks with menace, creeping forward on its chicken legs, but the sky behind has an 
evening glow, and warm light spills from the house. Will they be welcomed or turned into soup? I love the Baba Yaga tales for their brilliant darkness and moral ambiguity, and that's what I aimed to portray in the image. Her house is animalistic, perched on its chicken legs. She is quite literally at home in the wild animal world. (Do Rozario and Carrington 3)

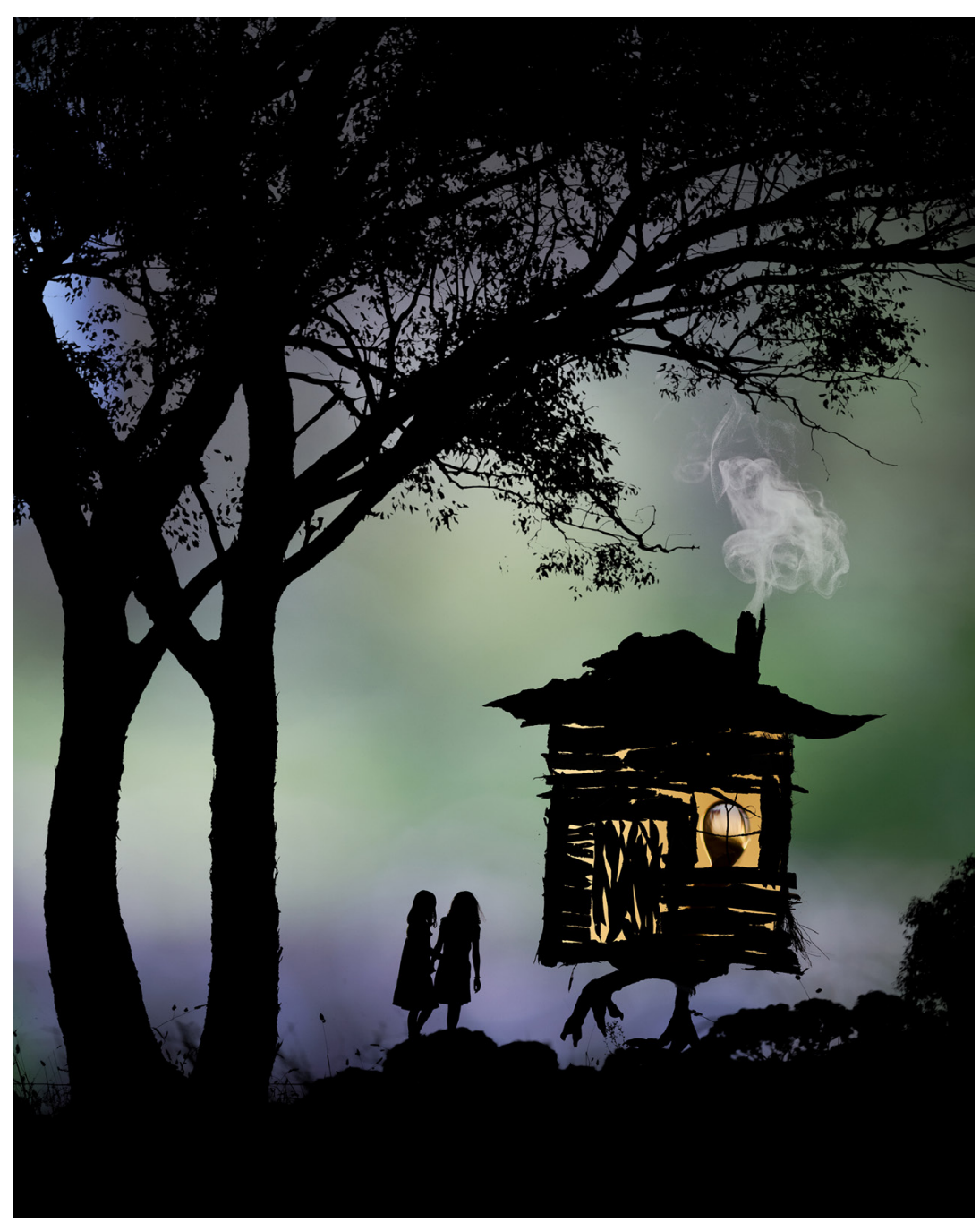

Fig. 1. "Will they be welcomed or turned into soup?" The fate of the children approaching Baba Yaga's house in Lorena Carrington's image is unknown. Image reproduced with kind permission of the artist. 
Here (see fig. 1), Carrington not only reiterates the importance of Baba Yaga's ambiguity, but echoes Johns's assertion that Baba Yaga functions as a "liminal, borderline character, mediating between human and supernatural, human and nonhuman" (271). Perhaps it is this liminality that gives Baba Yaga such narrative potential at this moment in history, which some describe as part of a new Anthropocene epoch: a time in which humans are becoming aware that their impact on the planet may be permanent and in which the boundary between the human and nonhuman is being investigated with a spirit of urgency. Just as the Bluebeard tale was uniquely suited to being retold in the post-World War II era, when wives were coming to terms with returned-soldier husbands and their violent secrets (Tatar), it may be the case that Baba Yaga tales retellings increase in frequency in this era of mass environmental destruction and soulsearching about the nature of humanity. After all, fairy tales are often used as "interpretative tools, devices to explore and think with, not telling the reader or audience what to do or how to behave, but instead offering a metaphorical scaffolding upon which real problems might be modelled" (Ashley n.p.).

My project is not to put Baba Yaga in the Australian bush, but to locate her in the Tasmanian bush. Geopolitically, the latter is considered a subset of the former; however, there are reasons that the two locations are distinct. Australia has six states and, of these, only Tasmania is an island. Once known as Van Diemen's Land, Tasmania is cold, wild, and mountainous: a place deeply haunted by the systematic brutality of its history of colonial dispossession. A confluence of history, topography, and climate has meant that certain kinds of artistic expression have taken root in Tasmania while they have not simultaneously flourished in mainland Australia. Especially, Tasmanian culture has an affinity for the Gothic. Roslynn Haynes argues persuasively that "the Gothic genre provided startlingly appropriate metaphors for colonialism," where the colonist occupied the role of "Gothic victim thrust into an alien territory" (219), and while elements of the Gothic appeared in tales of lost children set in mainland Australia, the heat and trackless deserts of the continent failed to meld fully with the traditions of Gothic writing. But Tasmania, with its wet, cold, impenetrable landscapes, strange beasts, foundational narratives of extinction, and fireside tales of cannibalistic convicts, took up the Gothic with a vengeance. In Tasmanian writing, says Haynes, the Gothic is "waiting in the wings, ever on call to liven up a flagging novel, either as innuendo or, more often, as ghosts haunting the landscape" (230).

The Gothic, says Dale Peterson, hinges on contemporary characters and settings being violently disturbed "by the posthumous vitality of an ancestral presence or artefact" (38). Further, Gothic tales often hinge on the "power of the past to command a repeat performance despite the conscious will or rationality of a present-day mentality" (38). As I have worked to capture my Baba 
Yaga through the method I explained earlier-through the reading of primary and secondary sources, through thinking and experimental writing - this idea of the Gothic has exploded outwards in numerous directions at once. In one direction, it seems that Baba Yaga — with her Russian heritage, her monstrousness, and the way she evokes a pagan, matriarchal past—can be made perfectly at home in the Tasmanian Gothic. More metafictionally, I have wondered if there is any better description of a mystical invitation to reinvent a fairy-tale character than the power of the past to command a repeat performance.

But, and as I have discussed elsewhere (Wood), Australian writing has a tense relationship with the fairy tale (and Elizabeth Bullen and Naarah Sawers have written about a similar tension in Australian film). To summarize-and, here, I am slicing this discussion back to the marrow-Australia is at once fascinated by, and frightened of, the fairy tale. Canadian scholar Lisa Fiander theorized that the term fairy tale is very often mobilized in Australian contemporary fiction when a writer wishes to signal a white-settler character's feeling of displacement within the Australian bush (157). In Australia, the magical incantation "once upon a time" causes anxiety because Australians' sense of time is broken by the thing that used to be called settlement and is now at least as often called invasion. "Once upon a time," by forcing attention upon the illegitimate founding of the Australian nation, has the effect of rattling chains, prodding closeted skeletons, and unsettling the murky sediment of colonial past.

It's my observation that contemporary Australian writers who engage with fairy tale fall, broadly speaking, into two camps. The first camp is made up of those who retell stories from the European tradition, but set them in Europe or in fantasy settings. The other camp is made up of those who fracture tales from the European tradition and embed the shattered pieces in contemporary fiction that is set in recognizably Australian settings. It seems that the more whole the fairy tale is that is being retold, the less likely it is that the setting of the retelling will be recognizably Australian, as if Australian writers have developed a tacit agreement that European fairy tales are safely told in the Australian bush only after being broken down into small pieces.

On the one hand, white Australian society will do just about anything to avoid looking too directly at the colonial moment; on the other hand, there is in culturally sensitive circles a strong desire to avoid causing offense to indigenous Australia. Generally, it is not considered appropriate for white Australian writers to engage with indigenous Australian mythologies, but it seems to have been equally problematic for white Australian writers to engage with European mythologies on Australian soil and for postcolonial Australia to invent fairy tales of its own. Contemporary white Australian writers, rightly, want to avoid using European fairy tales to create a new wave of colonialism. Or, to be slightly less generous, it may be that they wish to avoid being criticized for so 
doing. Things are changing, however, and exciting possibilities arise when indigenous writers undertake fairy-tale revisions in an Australian context, as Alexis Wright does in her postmodern epic The Swan Book (2013).

So, while it seems to me that Baba Yaga could be made welcome in the Gothic environment of the Tasmanian bush, such a project inevitably interrogates the politically sensitive complexities that arise whenever one considers transporting elements of the European fairy tale into any part of the Australian bush. To imaginatively install Baba Yaga's ancientness might be read as a violation: the equivalent of colonizing the precolonial continent, which would be a retrospective act of imaginative possession and penetration. The idea of it is enough to bring to mind Frantz Fanon's words:

Perhaps we haven't sufficiently demonstrated that colonialism is not satisfied merely with holding a people in its grip and emptying the native's brain of all form and content. By a kind of perverted logic, it turns to the past of the oppressed people, and distorts, disfigures, and destroys it. (210)

I have wondered if it is the case that European fairy tales can't live in the Australian bush except through risking imaginative violence. But I don't want to believe this is true. I want to believe that we live in a global world where it is possible and desirable for currents of thought and imagination, heritage, and tradition to intermingle in a decolonial poetics and politics. I want to believe that creativity means there's always another way-a way of bringing together disparate traditions. And what I have learned from my years of writing novels, alone and in collaboration, is that the avenue to this other way is through the question "What if"?

What if this Tasmanian-bush Baba Yaga of mine was a derivative not entirely of the human, but also of the nonhuman? What if the Tasmanian devil that arrived as part of the idea that "came to me" was not only under the floorboards of the house on legs, but also-in a sense-inside Baba Yaga? The Tasmanian devil's Latin name is Sarcophilus harrisii-literally, Harris's flesh eater. The creature was named devil by Europeans who were unsettled by its perceived ferocity. Since humans caused the extinction of the thylacine, or Tasmanian tiger, the devil has become world's largest marsupial carnivore. Like Baba Yaga, the devil carries with it a cultural history of ambiguity. In the history of white Australia, the animal has been much hated and deliberately persecuted. But it has also been revered and cherished, at least in its more harmless, culturally produced incarnations. Stylized images of the Tasmanian devil have been used to sell everything from fudge to beer, tourism to motorcycle helmet-visor wipes. The animal is most recognizable, globally, in its 
Warner Brothers cartoon incarnation, which may or may not have been inspired by another Tasmanian icon: Hollywood actor Errol Flynn.

At present, Tasmanians devils face two significant threats. One is devil facial tumor disease (DFTD), which is a contagious cancer first recorded in 1996 that has devastated devil populations. The other is an older foe: the motor vehicle. An estimated 300,000 animals (including kangaroos, wallabies, pademelons, bandicoots, possums, potoroos, echidnas, wombats, bettongs, quolls, and devils) are killed on Tasmanian roads each year, and wildlife carers are kept busy raising the young that are often found in the pouches of roadkilled females. While baby Tasmanian devils are very cute, and hand-raised pups can for a time be almost cuddly, this pretense of domesticity cannot hold. All devils, finally, grow up to be profoundly and incorrigibly wild. Like nature itself, the devil (and Baba Yaga) operate according to nonhuman codes of conduct.

A crucial part of the idea that "came to me" was that my character lived high on a hillside, above a dangerous road, and it was in Mayako Murai's book From Dog Bridegroom to Wolf Girl (2015) that I came for the first time upon the "yamauba," or "mountain witch" of Japanese folklore (20), which is a figure capable of transformation into nonhuman forms. What if my character was related not only to Europe's Baba Yaga, but also to the mountain witches of Japanese fairy tale? Might this mean that rather than looking only backwards towards a European mother country, my new story might also look forward, anticipating new, globalized forms of hybridity?

These are questions that will not have answers until the work is complete and perhaps not even then. During the writing process, however, they will continue to act as provocations and guides.

\section{Works Cited}

Ashley, Melissa. "And Then the Devil Will Take Me Away': Adaptation, Evolution, and the Brothers Grimm's Suppression of Taboo Motifs in 'The Girl without Hands." Double Dialogues, issue 12, 2010, www.doubledialogues.com/. Accessed Nov. 12, 2017.

Bullen, Elizabeth, and Naarah Sawers. "Australian Fairy-Tale Films." Fairy Tale Films beyond Disney: International Perspectives, edited by Jack Zipes et al., Routledge, 2015, pp. 233-45.

Do Rozario, Rebecca-Anne, and Lorena Carrington. "Crafting Baba Yaga from the Australian Landscape: An Interview with Lorena Carrington." Text, Into the Bush: Australasian Fairy Tales, special issue 43, 2017, www.textjournal.com.au/speciss/ issue43/DoRozario\&Carrington.pdf. Accessed Dec. 5, 2017.

Fanon, Frantz. The Wretched of the Earth. Grove Press, 1963. 
Fiander, Lisa. "Writing in a 'Fairy Story Landscape." Journal of the Association for the Study of Australian Literature, vol. 2, 2003, openjournals.library.usyd.edu.au/ index.php/JASAL/article/view/9668. Accessed Feb. 12, 2016.

Gilbert, Elizabeth. Big Magic: Creative Living beyond Fear. Bloomsbury, 2015.

Haynes, Roslynn D. Tasmanian Visions: Landscapes in Writing, Art and Photography. Polymath, 2006.

Johns, Andreas. Baba Yaga: The Ambiguous Mother and Witch of the Russian Folktale. Peter Lang, 2004. International Folkloristics, vol. 3.

Joosen, Vanessa. Critical and Creative Perspectives on Fairy Tales: An Intertextual Dialogue between Fairy-Tale Scholarship and Postmodern Retellings. Wayne State UP, 2011. Series in Fairy-Tale Studies.

Marillier, Juliet. Prickle Moon. Ticonderoga, 2013.

Murai, Mayako. From Dog Bridegroom to Wolf Girl: Contemporary Japanese Fairy-Tale Adaptations in Conversation with the West. Wayne State UP, 2015. Series in FairyTale Studies.

Peterson, Dale. "Russian Gothic: The Deathless Paradoxes of Bunin's Dry Valley." The Slavic and East European Journal, vol. 31, no. 1, 1987, pp. 36-49.

Tatar, Maria. Secrets beyond the Door: The Story of Bluebeard and His Wives. Princeton UP, 2006.

Ugrešić, Dubravka. Baba Yaga Laid an Egg. Translated by Ellen Elias-Bursac, Canongate, 2010.

Wood, Danielle. "Strategic, Stylistic and Notional Intertextuality: Fairy Tales in Contemporary Australian Fiction." Text, Into the Bush: Australasian Fairy Tales, special issue 43, 2017, www.textjournal.com.au/speciss/issue43.pdf. Accessed Nov. 7, 2017.

Wright, Alexis. The Swan Book. Giramondo, 2013. 